6-5-2008

\title{
Gendered leadership: An organizational perspective
}

Pamela L. Eddy

College of William and Mary, pamela.eddy@wm.edu

Elizabeth M. Cox

Follow this and additional works at: https://scholarworks.wm.edu/educationbookchapters

Part of the Community College Leadership Commons

\section{Recommended Citation}

Eddy, Pamela L. and Cox, Elizabeth M., "Gendered leadership: An organizational perspective" (2008). School of Education Book Chapters. 31.

https://scholarworks.wm.edu/educationbookchapters/31

This Book Chapter is brought to you for free and open access by the School of Education at W\&M ScholarWorks. It has been accepted for inclusion in School of Education Book Chapters by an authorized administrator of W\&M ScholarWorks. For more information, please contact scholarworks@wm.edu. 
This chapter provides a portrait of women's representation in the leadership ranks of community colleges and reviews data on how six women presidents talk about their lived experiences at the helm of their institutions. Findings indicate an uneven playing field for women on their way to a presidency.

\title{
Gendered Leadership: An Organizational Perspective
}

\author{
Pamela L. Eddy, Elizabeth M. Cox
}

Community colleges are regarded as democratic institutions, admitting anyone through open access and bringing educational opportunity to those not welcomed at many other institutions. Among the individuals welcomed at community colleges are those considered of low socioeconomic status, the unemployed, minority group members, and new immigrants to the United States. Yet those who occupy the leadership roles of the "people's colleges" do not mirror the diversity that is represented in community college enrollments. Women fill only 29 percent of all community college presidencies (American Council on Education, 2007), whereas they comprise 57 percent of students at these institutions (National Center for Education Statistics, 2004). Thus, the bulk of current community college leaders are members of the dominant class, race, and sex.

The next decade is predicted to see dramatic changes within community college leadership in the United States. According to the American Association of Community Colleges, almost 80 percent of current community college presidents plan to retire by 2011 (Shults, 2001). Indeed, the American Council on Education's recent survey of community college presidents shows that 44 percent are over sixty-one years of age (American Council on Education, 2007). This dramatic statistic places a strain on the community college system and puts leadership development in the forefront of issues facing community colleges. Will this mass exodus of presidential leadership, currently dominated by middle-aged white males, open the door for women and minorities to have more of a presence in community college

\section{(3)WILEY}

\section{InterScience}


leadership, or is the organizational culture of community colleges such that the status quo will be replicated and maintained? Currently less than onethird of two-year presidents are women, and this representation has not changed significantly in the past five years (American Council on Education, 2007). This chapter describes research conducted to create a portrait of women leading community colleges and examines the influence of gendered organizational structures.

\section{Leadership Overview}

Amey and Twombly (1992) studied leadership at community colleges and concluded that the language used to recount the organizational development of the community college sector reinforced male norms for leadership; it was based on research by and about a relatively small collection of white male scholars and practitioners. Research on women's leadership clearly documents that women are judged against male norms (Chliwniak, 1997; Monroehurst, 1997). Kanter (1993) noted the masculine ethic in management and the feminization of clerical work and concluded that bureaucratic structures give power through activities and alliances, most often to the exclusion of women. Little has changed in organizational structures since Kanter posited this relationship over a decade ago. Acker (1990) coined the concept of gendered organizations to highlight the advantages the male norm brings to the distribution of power. Organizations are the "products and producers of gender-based power relations, and ... masculine ways of doing things are inherent in structural, ideological and symbolic aspects of organization, as well as in everyday interactions and practices" (Hatch and Cunliffe, 2006, p. 274). Acker's framework served as the backdrop for this study.

Acker (1990) argued that gender is not an addition to ongoing processes but is instead an integral part of those processes. Acker posited that gendering in organizations occurs in at least five interacting processes: the construction of divisions along gender lines; the construction of symbols and images that explain, reinforce, or oppose those divisions; the interactions between women and men, women and women, and men and men that enact dominance and submission; the production of gendered components of individual identity; and the ongoing processes of creating and conceptualizing social structures. An example of this gendering is the conceptualization of the job and job evaluation. Within organizations, jobs are seen as being separate from individuals; they have a certain place within the hierarchy of the organization that is congruent with the job's level of responsibility and complexity and are independent of any concrete worker. Thus, hierarchies and jobs are seen as having no occupants, no human bodies, and thus no gender.

Two of the fundamental components to gendered organizations are the disembodied worker and the job (Acker, 1990). The disembodied worker represents a male whose life centers on his full-time job while a woman takes care of his personal needs. Organizational hierarchies are constructed on 
gendered processes and the underlying assumptions of the disembodied worker and the job. With these assumptions permeating organizations, masculine attributes pervade work and organizational processes. Acker (2006a) noted that gender inequalities are apparent by "the relative scarcity of women in most top level positions and the existence of large job categories filled almost entirely with low-wage women workers with little power and autonomy" (p. 111). Furthermore, Acker (2006b) observed the need to desist from blaming women for the inequities in organizations. Phillippe and Sullivan (2005) reported that in today's community colleges, women constitute the majority of nonprofessional staff ( 65 percent), which includes secretaries, clerks, and maintenance. This statistic, coupled with the fact that only 29 percent of community colleges are led by women and the other inequities described, paints the portrait of community colleges as gendered organizations. Given these demographics, Acker's model provides a useful means for better understanding two-year institutions as gendered organizations.

\section{Project Summary}

This study analyzed audiotaped and transcribed interviews with six women community college presidents. Each of the women had been leading her institution for less than five years; one participant was serving in her second presidency. Pseudonyms are used to protect the identities of the participants.

To discover more about the gendered nature of community college leadership, a phenomenological research method was employed. Phenomenology research searches for the central underlying meaning of an experience-in this case, the construction by women community college presidents of work within a gendered organization — and uses data reduction to analyze specific statements and themes for possible meanings (Creswell, 1998). This research methodology focuses on how individuals consciously develop meaning through social interactions (Creswell, 1998). We also employed a heuristic lens for deeper interpretation of the experiences described (Van Manen, 1990).

The women leading the campuses in this study did not do so without a context. As noted, 29 percent of all colleges are led by women. The women in the study had spent the majority of their careers working within community colleges. Four of the six ascended to their positions through previous administrative positions, with only two taking the traditional faculty route to a chief academic officer prior to their presidency. All of the women were currently married, whereas only 83 percent of all two-year public community college presidents are married (American Council on Education, 2007).

Cathy Voss is in her first presidency. Previously she held faculty rank at a community college, ultimately moving up to vice president of enrollment services prior to her presidency. Like Voss, Lori Cannon started her career as a faculty member, advancing to department chair, division dean, and vice president of academic affairs prior to her presidency. Maria Smith and Jennifer Cochran started their careers in the K-12 arena. Smith was a curriculum 
director prior to moving over to community outreach at the community college. She moved from this position to vice president of academic affairs and next to her presidency. Cochran was a high school business teacher, moving over to the community college central office to manage curriculum. She held a central office position in the community college district prior to being tapped by the chancellor of the system to take over as the community college president. Like Cochran, Denise Webster was also tapped by her chancellor for her current presidency. She had been the president of another college in the district prior to this move. Finally, Cindy Hales came to her presidency from the position of dean of students.

\section{Findings}

Findings from this research uncovered an organizational structure in community colleges still based on male norms. In particular, the role of the hierarchy and its corresponding reporting structure were present. Although some of the women described their leadership as open and participatory, the hierarchical structure was most apparent. The experiences of these women leaders showcase the types of behaviors that were rewarded as they ascended to the presidency, with links to the disembodied worker inherent in these descriptions.

Embodied Family Life. As the college presidents described their pathways to their current positions, they often noted the serendipitous routes they took along the way. Two of the six women did not pursue a presidency until their husbands retired. Two others intentionally chose their college because of family obligations. The remaining two women worked in a large urban area, giving them increased employment options. Moreover, these latter two were tapped by their male chancellor for their positions, resulting in obtaining presidencies within their district without a formal search or a need to move.

Several of the women noted a defining moment in which they realized they wanted to pursue a presidency. As Voss explained, "I was doing some consulting work with a president who was struggling with his board and was struggling with faculty. He asked me, "How should I handle this? Would you talk to the board?' And I thought—wow, I could be doing this job!" Fit was of prime concern for her in her search. She visited another institution that was seeking a president but came away thinking it did not feel right.

Since all of the women in the study were married, they had to deal with dual career issues when contemplating a move. One president commented, "Two-academic-career families are hard to find. My husband is a professor of mathematics and retired to come here with me. ... He got the little spouse tour during the interview." Family played a role for Hales in the move to her current college. She picked the college based on its location and the fit for her family. When the previous president announced his retirement, a male colleague who had been critical of the college indicated to her that he was going to be the next president. Hales reflected, "I tell you, that's 
enough to take your breath away. And, you know, he had made this announcement to me not even thinking that anybody perhaps in the same leadership team might be interested in being the president too. But in his mind, it was a done deal because he was the man for the job. And then I thought, "Well, they may not take him, but (they may take someone besides him). And that would be really terrible for the college." After conversations with the outgoing president, Hales decided to pursue the presidency herself and ultimately was selected for the position.

Lori Cannon historically made career choices with her family in mind. When her son was a toddler, she was an associate dean. She reflected:

I decided to get out of it because it was just obvious to me that I wasn't giving my child the attention that he needed. At some point, there are fewer administrative positions at an institution. . . It was just clear to me at that point when he was just three or four years old that I could not take an administrative position and protect what was important to me, which was the stability of my marriage, my son's growing up in a stable environment. By the time my son was through with college, it was just my husband and me. I thought, I'm not going to spend the rest of my life teaching the same courses every year. So at that point, there was an opportunity to take an interim academic dean position.

The idea of the disembodied worker and male norm of academics worked against Cannon in the choices she made. She did not make a move back to administration until her son was out of college and did not move to her presidency until her husband retired from his academic career.

Smith reflected on the possibility of seeking another presidency: "I consciously made a decision very early on that my first priority would always be my family. ... If someone offered me a job across the country, I'd love it, but it would take me away from my family. I wouldn't even think about it." Smith had recently been asked to apply for the presidency at a nearby college and opted to pass on the opportunity. She stated, "I just believe that if you do what's right, other opportunities will come, if it should be. Will I ever look for another job? Well, let's put it this way: it's not my career goal, but nothing has ever been my career goal. If something should come up, I would probably take a look at it, but is it my desire to leave? No." The lack of career planning and intentionality for advancement marked Smith's career pathway, as it did many of the other women in the study.

For Cochran and Webster, their presidencies started without a typical search. Instead they were appointed to their positions by the chancellor of the system. Both women had wide experience within the district and the state, making them desirable candidates. As insiders, they were able to enact changes quickly since they did not have to take the time to learn the system. The fact that they could stay within the system meant they did not have to move their families to take a promotion. 
Clearly the sequencing of career choices for the women in this study underscores the perpetuation of the disembodied worker in community colleges. The women were all in married relationships, some with children, and they made choices of when to seek advanced positions based on when their lives more mirrored that of their male counterparts: when their children were older or grown and their husband's careers could accommodate the move. This valuing of the public (male) over the private (female) spheres meant the women in the study ultimately had to embrace the male norm in order to secure career advancements.

Getting Tough. Language often serves to reinforce the concept of gender in leadership. West and Zimmerman (1987) refer to "doing gender" as the ideal of societal expectations based on gender. Women are often penalized for acting in ways that are outside what is expected of them. Paradoxically they are at the same time judged against male norms. When gendered organizations value the disembodied employee, the expectations are for women to fit this male-normed mold. One of the presidents told the story of being forceful in her side of an argument and being called a "bitch." She reflected, "I walked out of his office and said, 'I can't work for this man, and what's more, I probably can't work for anyone. I've got to be my own boss." Indeed, she was penalized for acting tough outside her gender. Another president, petite in stature, noted that a female board member advised her to wear glasses "to appear more serious." The women needed to act tougher to meet the expected work roles but could not appear too tough.

The women used language that reified their gender, allowing them to support traditional gender roles. Voss reflected, "I spoke in my first convocation that I was particularly well suited to this challenge because we had raised a family on a single faculty member's salary, since I didn't work when our children were young. But I was always pinching pennies and managing_-so I was well equipped for this job." Playing to the gender role reified female expectations.

One president stated, "The campus needed somebody who had some strong leadership but also would be willing to be a team player." The notion of the hero leader is embodied in this statement. In order for her to succeed, she needed to be a tough role model. She added, however, that when she walks around campus, "I frighten people." They wonder, "What's she here for?" "What's she looking for?" Her strong persona translated to her negatively perceived campus presence.

Denise Webster reflected on her preparation en route to her presidency: "I've had some experiences where there were institutions that did not want to change-that was a painful lesson, but it was a really good experience that was pretty valuable for me-not comfortable, but boy, you can learn a lot from being in an institution where change is just really rejected as a value." Here the value in the experience was learning how to make the hard decisions that were unpopular. 
Working in a Man's World. Emerging definitions of leadership are expanding to be more inclusive of others in locations outside the presidency. Yet research shows that half of the leaders in a recent study indicated their position was why they were a leader (Eddy and VanDerLinden, 2006). Thinking about what it means to be a leader is rooted in self-conceptions of values. The women in this study commented on why they wanted to be a president. For some, it was a realization that they were capable of doing the job, for others it was the fact that they could not work for another person.

The links of leadership to positional power begin to reify the gendered organizational structure of community colleges. Several of the women had mentors who viewed the presidency as a career goal. The support and identification of positional power reinforced the ideal of single leadership, which exemplifies the gendered congruence between responsibility, job complexity, and hierarchical position. Unfortunately, the hierarchy is based on the assumption that leaders can concentrate solely on work because there is someone on the home front supporting the leader. The model of positional leadership as the pinnacle of success begins to leave no alternative role models for women coming up through the ranks of the college. The bind for women is that the quickest route to the upper-level positions is to mirror the practices currently expected, which are based on the disembodied worker.

President Smith followed another woman when she took over her presidency. It was clear the previous president used her position as a steppingstone. Smith astutely concluded, "I found that kind of hurt me when I came because everyone thought this would be your stepping-stone because you're not old enough [to retire from the college in the near future]." The fact that the women were judged by the actions of the women before them set up a dilemma: not only were they judged by the male norms of organizations, they were measured against what other women prior to them did in the position, which made it difficult to be authentic in their leadership.

Lori Cannon stated frankly, "I know I have the same traits as all presidents do. I want to get things done." What remains implicit in this statement is that these traits are those associated with men, in particular the desire to have a product to show for effort versus typically attributed female traits of working on relationships without a specific measurable outcome. Cannon further noted her aspirations for a presidency. The internal desire to move up in responsibility based on her awareness of her ability to do the job illustrates her increased agency. The desire to be in the position in which the ultimate decisions are made, however, also reifies the male normed hierarchy.

One of the first actions of several of the presidents was to reorganize the hierarchy. In all cases, the changes added structure to the hierarchy and inserted a formal chain of command. The need for additional leadership midway in the hierarchy provided the rationale for these moves. One president commented, "I couldn't get breathing room. I had people at my door constantly!" The addition to the leadership ranks provided a level of protection 
for the new presidents and served to reinforce the idea of position as the critical factor for leaders.

Cannon discovered challenges facing her college in her first year when the college self-study report was published. She said, "This was the first inclination I've had or intimation that I've had that anything is seriously wrong. And is it my problem? Have I not been sufficiently attentive picking up these signals?" Obviously these problems existed prior to her talking over the helm. The experience affected her to the extent that she decided that if she obtained another presidency, she would request letters of resignation from all senior staff to hold in the event she needed a mechanism to clean house. She learned the need to operate in a more masculine way of leading by this experience. Many of her comments regarding changes she had made since becoming president were done as a means to gain some control. She concluded, "I'll be frank about it: the college has been a real trial. This has been a difficult job." The challenge of being judged against two sets of expectations, the male norms anticipated for the president and acting like a woman while doing this, took their toll.

Breaking Away. Not all elements of these women's presidencies were male influenced. Traditional women's ways of leading were also apparent. These feminized actions, however, still took place within a gendered organization. One president noted that she uses her leadership cabinet to bounce and formulate ideas. However, when she presented concepts to the larger campus, she did so using language of ownership, saying, "This is my plan," versus, "This is our plan." The ideas of others were incorporated, but the framing of them on campus relied on the role of position. She reflected, "I think the challenge for this campus is also to let go of stuff," which inferred that she knew the right direction.

Lori Cannon commented on her disciplinary background and its influence on her, "I'm not a typical physicist either. . . I think I'm a little more right-brained than that. Maybe it's my femininity that I bring to that. I don't know. But every single one of us is a unique human being with a unique set of past experiences. There probably is no way to plot that out as a model of leader development." Inherent in this reflection is an acknowledgment that things would be different if we acknowledge the feminist side of leading. Also evident was the role of agency in recognizing the role of experience in working toward change and adapting to circumstances in developing as a leader.

The personal ownership of the actions of the president for the college showcases a reliance on relationships, which are often viewed as being woman based. Smith stated, "First of all, when you're a president, if you want to do a really good job, I believe you have to really become part of the institution." Relationships were critical to the women as they took over the helm. Each indicated taking time to get to know campus members and campus issues.

An obvious breaking away of tradition was evident for Denise Webster's campus which was under construction. Webster stated: 
The vision came out of the ability to build a college from scratch in the twenty-first century, taking best practice of everything we all wish we could do but can't because there're always limitations either by organizations or by people you have employed, or by habit, or by physical plant and to really then take full advantage of the opportunity to take the blank page and actually build a learning college.

The ability to start from a blank page allowed for an intentional break from a bureaucratic operation based on male norms and the disembodied worker. The barrier for a full change, however, was apparent even in this situation, since 50 percent of the new employees were hired from within the district. Webster noted, "We hope it will create a situation where there'll be more flexibility and more the ability to react or change-deal with change in less siloed ways to allow us to make those shifts." Still, she commented on the process of creating a new college: "We were encouraged to institute and formulate our organizational structure and really go pretty far out there, away from an academic structure. That's where being in a district limited us." She expanded, "We enjoyed exploring that [different structure], but when it came down to it, this district has vice presidents and deans, and we had to just hire people, have certain things that at least looked like other things in the district."

\section{Conclusion}

Community colleges are gendered organizations despite espoused values of being democratic institutions. Reliance on hierarchy and positional power is still evident, as in the creation of a new campus that still used a traditional reporting structure and the move by several of the presidents to add to the organizational hierarchy. The portrait of community colleges with more than a majority of women as students, but less than a third led by women, supports Acker's definition (2006a) of gendered organizations. Mere number increases in women's representation, however, do not address the larger issue of the male-normed organizational structure. Frame-breaking changes to these norms are required to create a gender-neutral institution.

A means of moving forward is the expansion of organizational and leadership research that deconstructs the hegemonic norm of male leadership defining all leadership. Certainly the women presidents represented in this research had expectations foisted on them to act or lead in a particular manner. Indeed, DiCroce (1995) provided a framework for action for women to effect meaningful change in their institutions. She outlined the following actions:

- Break down institutional gender stereotypes.

- Penetrate the institution's power structure, and redefine its sense of power.

- Use the power of office to alter gender-related institutional policy. 
- Raise collegial consciousness, and initiate a collegial dialogue on gender.

- Become an active player for public policy development and debate.

Organizationally the chance to build a college from the ground up may provide one means to get beyond the gendered organization. Another option for breaking away from entrenched patterns of behaviors may be through institutional partnerships. Collaborations may provide the basis for a way of rethinking power and leadership roles. For women who have obtained success in their careers to date by acting within the male norms, breaking away from this practice might be impossible since the behavior is ingrained. An increase in personal agency might allow change of these old behaviors.

There are actions that community colleges may take now to facilitate the move to a less gendered organization. The first of these is an acknowledgment that the goals and mission of the organization are not gender neutral, which ultimately will lead to changes in these documents (Ward, 2004). Next, the organization should identify the factors within the community college environment that are contributing to greater gender equality and replicate them throughout the organization (Britton, 2000). Finally, the community college should examine the ways the gendered practices within the organization are rewarded by outside organizations and move toward changing, if not eliminating, this system of compensation for gendered practices.

Research has shown that successful change projects like affirmative action and pay equity campaigns had common characteristics: they targeted a limited set of inequality-producing mechanisms (for instance, hiring practices), combined social movement and legislative support from outside the organization with active support from insiders, and involved coercion or threat of loss (Acker, 2006b). Yet until there is another period of broad social movements supporting organizational change, greater gender equality may be difficult to attain.

The research reported here found that a decade after DiCroce (1995) outlined her action plan of change for women leaders, transformation is still needed. Building on DiCroce's earlier arguments, Kramer (2005) noted, "Although agency may be limited to creating a means to survive within difficult social arrangements, it sometimes produces changes in the environment" (p. 5). Thus, individuals can begin to change the microenvironments within their institutions. Within organizations, power structures still form the basis of the hierarchy, women continue to be judged by male models of leadership, and gendered stereotypes persist. Despite this seemingly discouraging conclusion, this research provides a means of "giving voice to women in order to articulate feminist viewpoints, overturn unitary representations of experience to make way for the multiplicity of not only gender, but race, ethnicity, age, and class" (Hatch and Cunliffe, 2006, p. 275). Recognition of the work remaining to deconstruct gendered organizational structures within community colleges raises the issue to the forefront, offering a forum for dialogue for change and a site for additional research. 


\section{References}

Acker, J. "Hierarchies, Jobs, Bodies: A Theory of Gendered Organizations." Gender and Society, 1990, 4(2), 139-158.

Acker, J. Class Questions: Feminist Answers. Lanham, Md.: Rowman and Littlefield, 2006a.

Acker, J. "Inequality Regimes: Gender, Class, and Race in Organizations." Gender and Society, 2006b, 20(4), 441-464.

American Council on Education. The American College President. Washington, D.C.: American Council on Education, 2007.

Amey, M. J., and Twombly, S. B. "Revisioning Leadership in Community Colleges." Review of Higher Education, 1992, 15(2), 125-150.

Britton, D. M. "The Epistemology of the Gendered Organization." Gender and Society, 2000, 14(3), 418-434.

Chliwniak, L. "Higher Education Leadership: Analyzing the Gender Gap." ASHE-ERIC Higher Education Reports, 1997, 25(4), 1-97.

Creswell, J. W. Qualitative Inquiry and Research Design: Choosing Among Five Traditions. Thousand Oaks, Calif.: Sage, 1998.

DiCroce, D. M. "Women and the Community College Presidency: Challenges and Possibilities." In B. K. Townsend (ed.), Gender and Power in the Community College. New Directions for Community Colleges, no. 89. San Francisco: Jossey-Bass, 1995.

Eddy, P. L., and VanDerLinden, K. "Emerging Definitions of Leadership in Higher Education: New Visions of Leadership or Same Old 'Hero' Leader?" Community College Review, 2006, 34(1), 5-26.

Hatch, M. J., and Cunliffe, A. L. Organization Theory: Modern, Symbolic, and Postmodern Perspectives. New York: Oxford University Press, 2006.

Kanter, R. M. Men and Women of the Corporation. (2nd ed.) New York: Basic Books, 1993.

Kramer, L. The Sociology of Gender. (2nd ed.) Los Angeles: Roxbury Press, 2005.

Monroehurst, R. "Leadership, Women and Higher Education." In H. Eggins (ed.), Women as Leaders and Managers in Higher Education. Bristol, Pa.: Society for Research into Higher Education and Open University Press, 1997.

National Center for Education Statistics. Digest of Education Statistics, 2004. Washington, D.C.: U.S. Department of Education, 2004.

Phillippe, K. A., and Sullivan, L. G. National Profile of Community Colleges: Trends and Statistics. (4th ed.) Washington, D.C.: Community College Press, 2005.

Shults, C. The Critical Impact of Impending Retirements on Community College Leadership. Washington, D.C.: American Association of Community Colleges, 2001.

Van Manen, M. Researching Lived Experience: Human Science for an Action Sensitive Pedagogy. Albany: State University of New York Press, 1990.

Ward, J. "Not All Differences Are Created Equal: Multiple Jeopardy in a Gendered Organization." Gender and Society, 2004, 18(1), 82-102.

West, C., and Zimmerman, D. H. "Doing Gender." Gender and Society, 1987, 1(2), $125-151$.

PAMELA L. EDDY is associate professor in the department of educational leadership at Central Michigan University.

ElizABETH M. COX is assistant director of the California Community College Collaborative (C4) at the University of California, Riverside. 